\title{
下腿の複雑骨折に対する皮膚修復について
}

\author{
長愉大学整形外科教室（主任 : 永井三郎教授） \\ 難 波雄哉鳥越雄喜 \\ 田島直也
}

\section{Skin Coverage for Compound Fractures of the Leg}

By

\author{
K. Namba, T. Torigoshi and N. Tajima \\ Department of Orthopedic Surgery, Nagasaki \\ University, School of Medicine
}

緒言

下腿の複雑骨折の㓱が㓔痕治湶し, 且つ骨折部が偽 関節となつたものの中, 特に瘢痕が骨折部に痖着した り，骨折部を抢㧍う軟部組織が広く瘢痕化しているむ のでは, 瘷痕組織を除去して, 皮弁移植により局所の 血行を改善することが, 偽関節治療における一つの有 効な方法であることについては第25 回西日木整北災 害外科学会に報告したが, 今回は下腿複雑骨折の新鮮 時または，これに引き続いた時期における皮虑缺損の 修復について, われわれの症例を中心に皮唐修復の適 応の方式の撰択について検討を加えた.

下腿は骨折の頻度も高く, また, 解剖学的に脛骨前 面を㧍㧍う軟部組織が薄いため, 容易に複雑骨折をお こし, 骨が露出し易い部でもある.また, 同様の理由 でこの部の骨折は偽関節をおこし易すく, 開放創の閉 鎖や缺損皮䖉の修復にも特別の工夫のいるところであ ある。

\section{手技}

\section{1. 縫 合}

創を直接縫合して成功すれば最も簡単であるが，下 腿は外伤後の腫脤が強く，ために多くの場合このこて ろみは失敗に終る。

しかし，創の部位，程度によつては縫合のみによつ て創を閉鎖することあ可能で，慎重に適応を決定しな ければならない。

\section{2. 縫合と減張切開}

したがつて，直接創を縫合閉鎖するのが困難な場合
は，腫脹にそなえて減張切開を行ない外創を閉銧する 方法がとられる。

娍張切開の部位は，外伤による創の閉鎖を容易にし 日.つ外伤性腫脹による皮厙の過緊張をやわらげる目的 に合致するよう, 多くの場合, 開放創に平行した位置 に加えられるが, 部位としては筋層の厚い部位を撰 び, 切開創には直ちに中間層遊離移植を行なう.

\section{3. 遊離植皮}

外創を遊離植皮によつて閉鎖する方法である. しか し, 創が脛骨前面にあつて骨が露出しているあのには 適用出来ないため, 下腿の複雑骨折を遊離植皮単独で 閉銧することは少ないが, 筋首の厚い部位における開 放創や骨の露出があつても, 血行のよい剔離皮弁で骨 面が cover 出来るような例における皮膚缺損が厚い 筋層の部にあるようなものでは dèbridement に次い で遊離植皮によつて外創を閉鎖する場合むある。 ま た, 外傷後日時の経過により感染が強いものや肉芽の 発生したものなどで，直接皮弁移植が適当でないもの では先づ着床の容易なうすい遊離植皮で創を閉銷して から二次的に皮弁移植を行なうこともある.

\section{4. 虽離皮弁の利用}

下腿の複雑骨折では交通事故その他により大きな䟝 離を伴うことが少なくない.

このような場合の処置は, 䟝離された皮庯弁の血行 状態をまづ確認することで, 血行のよいものは勿論, 温存するが，乙の際，なるべく良好な厚い皮弁で骨面 を cover することを念頭に抽いて処置する.また， 䟝離皮弁で血行のないむのは, そのままの縫合は無理 であるが, 皮下脂肪を切除し遊離植皮の埸合と同様な 
手技によつて缺損創を゙ cover する。

\section{5. 局所皮弁法}

外創が比較的小さく，その隣接域に健常皮虞が充 分あるような複雑骨折では，開放創部を局所皮弁で cover し，局所皮弁採取部には遊離植皮を行なう。

このような例における，局所皮弁の作成部は下腿外 側の筋層の厚い部分が好ましく, 皮弁作成部が脛骨面 上にならないような注意が朋要である（図1）.

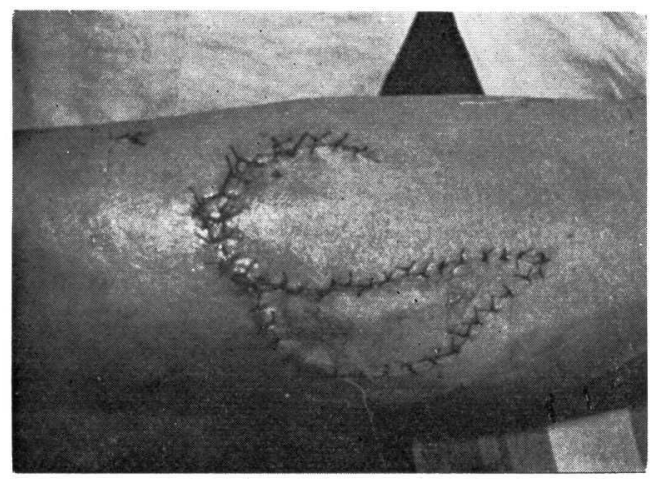

図 i

\section{Cross leg 法}

下腿の複雑骨折における創の修復にわれわれが最も 好んで利用する方法は，健側腓腸筋部よりの皮弁移植 である.

勿論，上記のような簡単な方法で目的が達せられる 場合は, 患者に与える苦痛む少なく効果の点でも充分 な方法がとられるのは云うまであないが，単なる縫合 や減張切開，局所皮弁等で修復困難な例では cross leg 法による健側下腿よりの皮弁移植が最も簡単であ り，且つ確実である。

しかし, 両下肢に外傷をうけたものに利用出来ない のは云うまでむないが，老人などではギプス固定にお ける肢位に無理のないよう注意が必要である.

\section{7. 腹部よりの大皮弁を利用する方法}

この場合は図 2 亿見るような下腿の広範な軟部組織 の缺損に対して行なうこのような広範な外創では cross leg 法による健側下腿よりの皮弁では不充分で あるので，側腹部に大きな皮弁を作製し，前腕部を carrier として下腿に移植する (図 3 ).

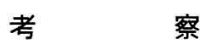

下腿複雑骨折におりる創の早期修復は，骨折部の瘜

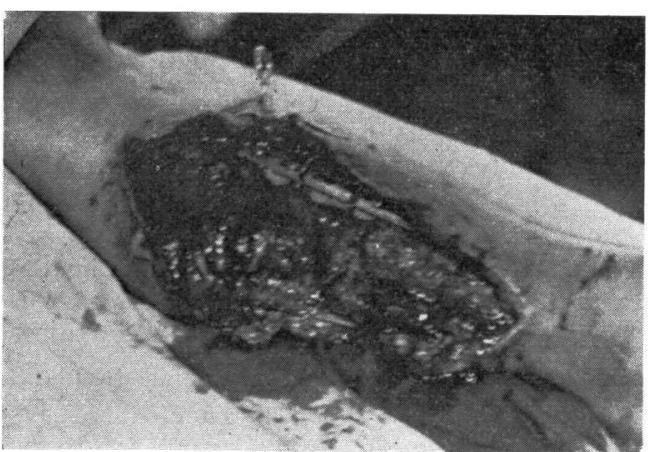

図 2

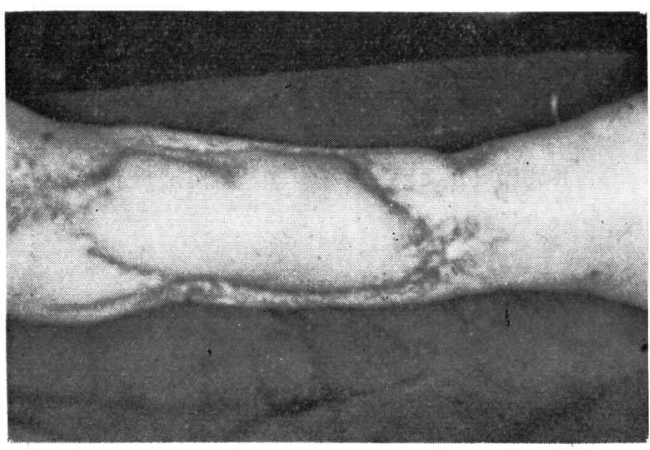

図3

合にとつても感染の防止にとつてあ極めて有効な処置 であるが，下腿は皮膚にゅとりがなく，脛骨も容易に 露出するため, 缺損軟部組織の修復には特に困難を感 じる部位である.

方法は既に述べた如く，創の位置や，外傷の程度に よつて一様でなく，それぞれの症例によつて適応を撰 択しなければならない。

創修復の時期は，感染の成立しない新鮮時が最も好 ましいが，受傷時の外力によつて挫滅した皮虚が時日 の経過にしたがつて次第に壞死にとなる場合もあり， 受傷頭初とれを判定するととに困難を感じることもあ るが, 䟝離創などでは新鮮時の dèbridement におい てよく血行の有無をたしかめなりればならない．ま た，新鮮時における骨折部の処置については，転位が 少なく比較的安定したものでは外創の修復によつて, 骨折部に対する特別の処置を行なうことなく治康をみ るが, 骨折部の転位が強く不安定なむのでは, 皮弁移 植術を行なうにも不便であるので，骨折部を整復回定 し, 安定した状態としてから移植術を行なう. 既任感 染のあるものでは，皮弁移植術後も瘦孔を作り排膿を 
みることがある.しかし局所感染による骨骮炎は早 晚, 治癒することが多いし, 病樂腒清術を行なうよし ても, 皮弁移植後 2 ケ月以上を経過し, 移梢皮弁が碓 実となつてから行うべきである.

\section{㐱考 献}

1) Connelly, J. S.: Pedicle coverage in nonuion of Jracture, Plast. \& Reconstruct. Surg., 3 : 727, 1948.

2) Connelly, J. S.: Bone problems in Plastic Surgery, Plast. \& Reconstruct. Surg., 17 : 129, 1956.

3) Coakley, W. A.: The use of direct form flaps in resurfacing defects of the soft tissues of the lower extremties, Plast. \& Reconstruct. Surg., 6: 413, 1956.

4) Jayes, P. H.: Cross-leg flaps, Brit. J. Plast. Surg., $3: 1,1950$.

5) Robinson, D. W.: Problems in fractures of the tibia, A. M. A. Arch. Surg., $63: 53,1951$.

6) Stark, R. B.: The cross leg flap procepure, Plast. \& Reconstruct. Surg., 9 : 173, 1952.

7) Stark, R. B.: Blood supply of cross leg pedicle flaps, Plast. \& Reconstruct. Surg., 3 : 694, 1948.

8) Stark, R. B.: Pre-operatively opplied, mated plaster of Paris casts as an aid in the migration of open-pedicle cross leg flaps, Plast. \& Reconstruct. Surg., $2: 433,1947$.

9）難波雄哉：植皮の手術とその要点（その2皮弁 移植術), 外科治療. $5: 727 \sim 733,1961$.

10）難波雄哉：下腿複雑骨折に対する皮弁形成術, 日本医事新報. $2056: 37 \sim 40$, 昭38.

11）難波雄哉：脛骨複雑骨折ならびに遷延治療骨折 に対する皮弁移植の手術と適応，手術．17(10)： 837, 炤38.

12）難波雄哉・他：下腿の複雑骨折に由来する遷延 骨瘾合に対する皮弁移植術について, 整形外科之 災害外科. 13(1) : 40, 昭38。

\title{
上腕骨外顆骨折の予後
}

久留米大学整断外科教空（主: 你: 察成成主: 教授)

$\begin{array}{llllllll}\text { 井 } & \text { 上 } & & \text { 博 } & \text { 柴 } & \text { 田 } & \text { 道 } & \\ \text { 宮 } & \text { 崎 } & \text { 守 } & \text { 正 } & \text { 田 } & \text { 平 } & \text { 浩 } & \text { 也 } \\ \text { 笹 } & \text { 原 } & & \text { 駿 } & \text { 岩 } & \text { 尾 } & & \text { 進 }\end{array}$

\section{On the Prognosis of the Fracture of the lateral Condyle of the Humerus}

By

\author{
H. Inoue, D. Shibata, M. Miyazaki, H. Tabira, \\ S. Sasahara and S. Iwao
}

Dapartment of Ovthopedic Surgery, Kurume University School of Medicine

\section{はじめに}

上腕骨外顆骨折の治療の原则は他の骨折の場合之同 様に確実な整復固定にある事は渝をまたない。容城教 授が翻転せる骨りをを整復針を用いて整復する経皮的整 復法を考案されてより, 吾々の教室では非推血的治 療, 推血的治療及び経皮的整復法の 3 つが, 症例に応 じて用いられてきた。
経皮的整復法を行なう以前の昭和 30 年に教室の前 田は木骨折の予後を 42 例につき種々の点より観察報 告したが，吾々は最近 11 年間に骨折治療を目的とし て来院した症例について機能的及び解剖学的予後を調 䄳し, 治療別等種々の点より検等した.

\section{1. 調查症例の概略}

昭和 28 年より昭和 38 年に至る 11 年間に外顆骨折 